\title{
Article \\ Effect of Ethanol Additives on Combustion and Emissions of a Diesel Engine Fueled by Palm Oil Biodiesel at Idling Speed
}

\author{
Guirong Wu, Jun Cong Ge* and Nag Jung Choi * \\ Division of Mechanical Design Engineering, Jeonbuk National University, 567 Baekje-daero, Deokjin-gu, Jeonju-si, \\ Jeollabuk-do 54896, Korea; wgr@jbnu.ac.kr \\ * Correspondence: jcge@jbnu.ac.kr (J.C.G.); njchoi@jbnu.ac.kr (N.J.C.); Tel.: +82-63-270-4765 (N.J.C.)
}

check for

updates

Citation: Wu, G.; Ge, J.C.; Choi, N.J.

Effect of Ethanol Additives on

Combustion and Emissions of a

Diesel Engine Fueled by Palm Oil

Biodiesel at Idling Speed. Energies

2021, 14, 1428. https://doi.org/

$10.3390 /$ en14051428

Academic Editors: Fernando

Rubiera González and

Makareviciene Violeta

Received: 11 January 2021

Accepted: 1 March 2021

Published: 5 March 2021

Publisher's Note: MDPI stays neutral with regard to jurisdictional claims in published maps and institutional affiliations.

Copyright: (c) 2021 by the authors. Licensee MDPI, Basel, Switzerland. This article is an open access article distributed under the terms and conditions of the Creative Commons Attribution (CC BY) license (https:/ / creativecommons.org/licenses/by/ $4.0 /)$.

\begin{abstract}
Biodiesel is known for its high cetane number and high oxygen content among other advantages, but its high viscosity and density are not trivial issues for fuel flow and atomization, especially under idling conditions. Due to low cylinder temperature and incomplete combustion, engine idling is one of the worst operating conditions. As a common fuel additive, ethanol can address some of the shortcomings of biodiesel. This work evaluated the combustion and emission characteristics of different concentrations of ethanol additives on a diesel engine fueled with palm oil biodiesel under idling conditions. The results show that ethanol helps to increase peak cylinder pressure and heat release rate, suppressing the production of certain emissions with a maximum reduction in smoke opacity of $71 \%$.
\end{abstract}

Keywords: biodiesel; ethanol additives; idling speed; engine performance; combustion and emission characteristics

\section{Introduction}

Diesel engines provide ample power for transportation, power generation, agriculture, and other fields. However, engines also consume a large amount of petroleum reserves, and the emissions released have adverse effects on the environment and humans [1]. With the increasingly tight fossil fuel reserves and stringent long-term emission standards for vehicle diesel engines, researchers have begun to explore clean resources that can reduce fossil energy dependence [2]. Among the existing diesel alternative fuels, biodiesel has been an object of attention of researchers. Biodiesel is a clean and renewable fuel that can be made from waste vegetable oil, animal fat, and non-edible vegetable oil through a transesterification process [3]. Compared to diesel, biodiesel is non-toxic, does not contain sulfur, and is biodegradable [4]. Due to the special structure of its main component fatty acid esters, biodiesel normally contains 10-15\% oxygen [4], which helps to more fully oxidize the fuel. Ge et al. analyzed the exhaust gas of a blend of biodiesel and diesel, finding that adding $20 \%$ biodiesel to diesel reduces volatile organic compound emissions [5]. However, there are some shortcomings of biodiesel including its higher density and viscosity, which adversely affect fuel flow and injection [4]. Mayo et al. found in the test that due to the deterioration of atomization and evaporation conditions, B100 (100\% soybean biodiesel) has a larger droplet size and a longer injection depth during the injection process [6]. Secondly, biodiesel is more corrosive than diesel, and the deposits and corrosive acids produced may aggravate engine wear [7]. Biodiesel contaminants may clog filters, fuel injectors, and aggravate the corrosion of the fuel system and the degradation of elastomer materials [8]. Fortunately, these shortcomings can be compensated for by adding suitable additives to biodiesel.

There have been many studies to change the physicochemical properties of biodiesel using additives. According to a report [9], metal-based additives, cetane number additives, and oxygen-containing additives have been used to improve the properties of biodiesel such as viscosity, flash point, and volatility, which help to improve combustion quality 
and reduce the generation of related pollutants such as soot. Kannan et al. added $\mathrm{FeCl}_{3}$ at different concentrations as a metal-based additive to waste cooking palm oil biodiesel, where it was observed that the cetane value and flash point of the fuel improved slightly, accompanied by reductions in HC, CO, and flue gas emissions [10]. Kumar et al. tested the effect of cerium oxide additives on B20 (20 vol\% waste cooking oil biodiesel + diesel $)$ under different injection pressures and found that $\mathrm{CeO}_{2}$ additives shorten the ignition delay of the fuel and increase the maximum thermal efficiency of the engine by $2.5 \%$ [11]. However, a qualified fuel additive should not only produce beneficial effects, but also be cost effective and impart low environmental impacts. As a common fuel additive, ethanol can be derived from renewable or discarded agricultural raw materials such as corn and wheat with good economic efficiency [12-14]. Although ethanol is not an ideal alternative fuel for diesel engines, it can be added to reduce fuel viscosity, cetane number, and flash point as well as increase fuel volatility and improve cold flow performance [15].

The scope of research involving ethanol additives in biodiesel or fossil diesel is relatively extensive. In a spray characteristics experiment conducted by Zhan et al., adding $20 \%$ soybean biodiesel to diesel increased the characteristic droplet size of the spray; however, after adding $20 \%$ ethanol, the droplets were optimized to the level of pure diesel [16]. Zhu et al. explored some characteristics of ethanol-biodiesel blended fuels under five loads of $0.08,0.2,0.38,0.55$, and $0.70 \mathrm{MPa}$ on an inline four-cylinder engine. They demonstrated that ethanol promotes higher pressure, increased heat release rate, and decreased emission of BSNOx [17]. Pradelle et al. tested the effects of 0,1 , and $2 \mathrm{vol} \%$ ethanol additives on the physical and chemical properties of diesel-biodiesel-ethanol blends and found that low concentrations of ethanol helped to slightly reduce the viscosity, density, and surface tension of the fuel as well as slightly increase the cold filter plugging point [18]. Madiwale et al. added ethanol to jatropha, soybean, palm, and cottonseed biodiesel containing $5 \mathrm{vol} \%$ diesel and found that braking power and braking thermal efficiency were improved, but braking-specific fuel consumption increased [19]. It can be seen that ethanol additives may have obvious effects in different ratios, multiple biodiesel and different test conditions.

When the engine is in the idling state, the accelerator pedal is not pressed down and the engine runs at a low speed, during which the output power only meets the working requirements of the water pump, generator, air conditioner, and other accessories. Under idling conditions, an engine cannot operate at a suitable temperature and the combustion quality is poor, which leads to increased emission levels [20]. Meanwhile, the fuel consumption of the engine and the $\mathrm{NOx}, \mathrm{HC}, \mathrm{CO}$, and other gas emissions are much higher than those in the driving state [21]. Although it is not unusual for ethanol to appear as an additive in blended fuels, the performance of ethanol-biodiesel fuel under idling conditions of diesel engines needs to be supplemented.

Palm oil is the main bio-oil species in Asian countries such as Malaysia and Indonesia [22]. Unlike other common raw materials such as soybean and rapeseed, palm is a perennial plant that can continuously produce biodiesel. Palm is not only the raw material with the highest oil yield $[23,24]$, but also has outstanding performance in terms of productivity, efficiency, and land use [24]. However, palm planting may cause more severe man/land crises and food challenges. The biodiesel produced also has the disadvantages of high viscosity, high density, and low volatility [25], which can be alleviated by adding proper additives. Moreover, we found that little attention has been paid to the performance of palm oil biodiesel under engine idling conditions. In this study, 0, 5, 10, and 15\% ethanol were added to pure palm oil biodiesel as the fuel of an engine to explore the effects of ethanol additives on the combustion, emission characteristics, and engine performance under idling conditions.

\section{Experimental Setup and Procedure}

\subsection{Test Fuels}

In this work, ethanol with $99.9 \%$ purity was used as an additive at different proportions when blended with pure palm oil biodiesel. Ethanol was added into biodiesel at volume 
ratios of $0 \%, 5 \%, 10 \%$, and $15 \%$, corresponding to $\mathrm{B} 100$ (100\% biodiesel $+0 \%$ ethanol), B95E5 (95\% biodiesel $+5 \%$ ethanol), B90E10 (90\% biodiesel $+10 \%$ ethanol), and B85E15 ( $85 \%$ biodiesel $+15 \%$ ethanol). The fuel properties are shown in Table 1 . The density, calorific value, viscosity, and cetane number of the biodiesels are greater than those of ethanol, but the oxygen content in ethanol is more than three times that of biodiesel. These differences in properties result in different combustion and emission characteristics.

Table 1. Fuel properties.

\begin{tabular}{cccccc}
\hline Properties (Units) & B100 & B95E5 & B90E10 & B85E15 & Ethanol \\
\hline Density $\left(\mathrm{kg} / \mathrm{m}^{3}\right.$ at $\left.15^{\circ} \mathrm{C}\right)$ & 877 & 873.12 & 869.24 & 865.36 & 799.4 \\
Calorific value $(\mathrm{MJ} / \mathrm{kg})$ & 39.72 & 39.19 & 38.66 & 38.12 & 28.18 \\
Oxygen content $(\%)$ & 11.26 & 12.43 & 13.6 & 14.78 & 34.7 \\
Viscosity $\left(\mathrm{mm}^{2} / \mathrm{s}\right.$ at $\left.40^{\circ} \mathrm{C}\right)$ & 4.56 & - & - & - & 1.10 \\
Cetane index & 57.3 & - & - & - & 8 \\
Flash point $\left({ }^{\circ} \mathrm{C}\right)$ & 196 & - & - & - & 12 \\
\hline
\end{tabular}

\subsection{Test Engine and Operating Methods}

The engine tested in this study is a turbocharged four-cylinder CRDI diesel engine with a displacement of $1991 \mathrm{cc}$ and with the exhaust after-treatment device removed. The engine specifications are listed in Table 2. The engine speed and load were controlled by an eddy current dynamometer (DY-230 kW, Hwanwoong Mechatronics, Gyeongsangnam-do, Korea). The pressure in the cylinder was measured by a piezoelectric pressure sensor (Type 6056A, Kistler Korea Co., Ltd., Gyeonggi-do, Korea) and recorded on a data acquisition board (PCI 6040e, National Instruments, Austin, TX, USA). The fuel consumption of the engine was determined using a high-precision digital electronic weighing balance (GP-100K, A\&D Co., Ltd., Tokyo, Japan). MK2 (GreenLine MK2, Eurotron (Korea) Ltd., Seoul, Korea) and HPC-501 (Nantong Huapeng Electronics Co., Ltd., Jiangsu, China) multi-gas analyzers were used to measure $\mathrm{CO}, \mathrm{HC}$, and NOx emissions. The smoke opacity of the exhaust gas was measured by an OPA-102 smoke meter (QROTECH Co., Ltd., Gyeonggi Province, South Korea). The engine speed was set at $750 \mathrm{rpm}$ to simulate idling, and the load was set to 30,40 , and $50 \mathrm{Nm}$ to simulate the operation of vehicle accessories. Pilot injection timing was adjusted to $18{ }^{\circ} \mathrm{CA} \mathrm{BTDC}$, and the main injection timing was at $5{ }^{\circ} \mathrm{CA}$ BTDC. The injection pressure was fixed at 350 bar. The engine operating environment was maintained at $25{ }^{\circ} \mathrm{C}$, and the cooling water temperature was $85^{\circ} \mathrm{C}$ when the engine was running smoothly. The experimental and operating conditions are shown in Table 3 . Figure 1 illustrates the engine test system.

Table 2. Specifications of the test engine.

\begin{tabular}{cc}
\hline Engine Type & 4-Cylinder 4-Stroke Direct Injection \\
\hline Fuel injection system & Bosch common-rail \\
Air system & Turbocharger with WGT \\
Bore $(\mathrm{mm}) \times$ Stroke $(\mathrm{mm})$ & $83 \times 92$ \\
Displacement $(\mathrm{cc})$ & 1991 \\
Compression ratio & $17.7: 1$ \\
Max. power $(\mathrm{kW} / \mathrm{rpm})$ & $82 / 4000$ \\
Injector hole diameter $(\mathrm{mm})$ & 0.17 \\
\hline
\end{tabular}


Table 3. Experimental and operating conditions.

\begin{tabular}{cc}
\hline Test Fuels & B100, B95E5, B90E10, B85E15 \\
\hline Engine load & $30,40,50 \mathrm{Nm}$ \\
Engine speed & $750 \mathrm{rpm}$ \\
Fuel injection pressure & $350 \mathrm{bar}$ \\
Pilot injection timing & $18^{\circ} \mathrm{CA} \mathrm{BTDC}$ \\
Main injection timing & $5{ }^{\circ} \mathrm{CA} \mathrm{BTDC}$ \\
Intake air temperature & $25 \pm 3^{\circ} \mathrm{C}$ \\
Cooling water temperature & $85 \pm 3^{\circ} \mathrm{C}$ \\
\hline
\end{tabular}

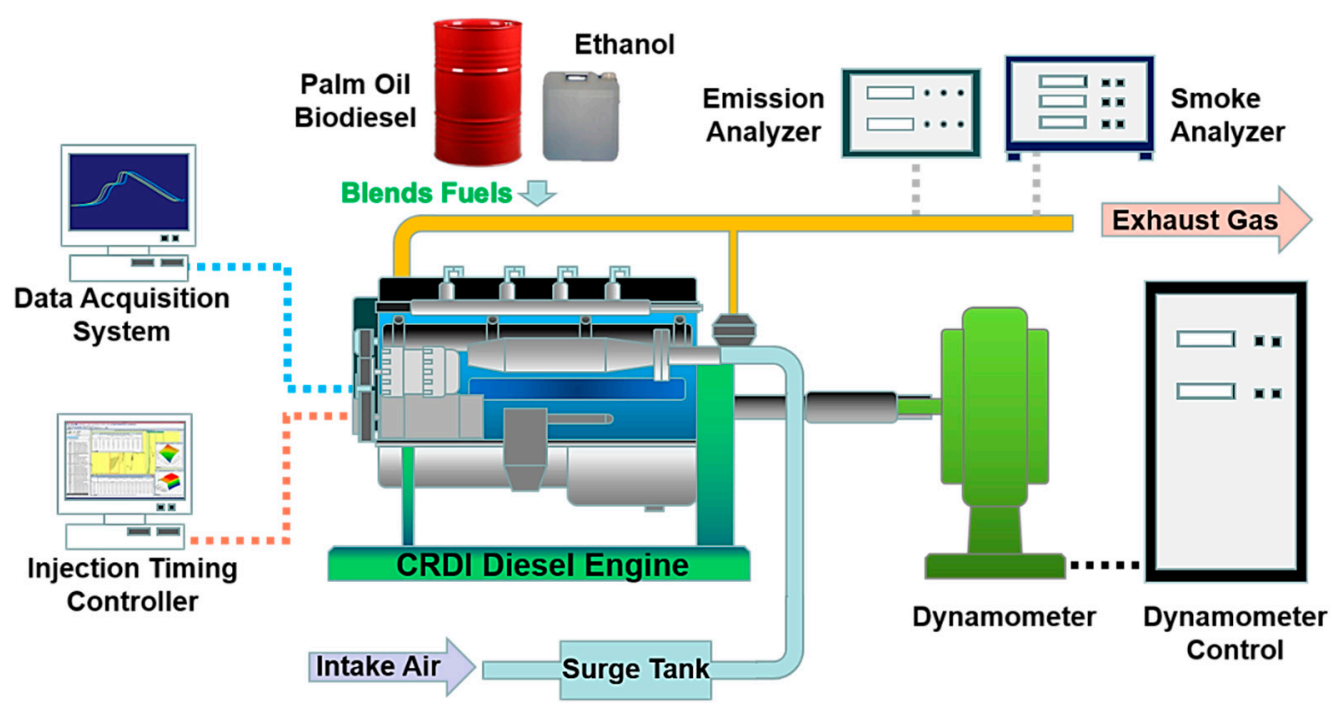

Figure 1. Engine test system.

\section{Results and Discussion}

\subsection{Combustion Characteristics}

The variations in cylinder pressure (CP) and heat release rate (HRR) of fuels with different concentrations of ethanol are shown in Figure 2. The combustion-related information from the CP and HRR graphs including ignition delay, combustion duration, in-cylinder peak pressure, and peak heat release rate is summarized in Table 4. For all fuels, high loads increase the peak cylinder pressure (CPmax) and maximum heat release rate (HRRmax). When the load was increased from 30 to $50 \mathrm{Nm}$, the peak pressure in the cylinder increased by $11.8 \%$ with B100, 13.3\% with B95E5, 12.7\% with B90E10, and 12.6\% with B85E15. Additionally, the CPmax and HRRmax values of ethanol-biodiesel are larger than those of pure biodiesel, and the peak values increase with increasing ethanol concentration. There was little difference in ignition delay at idling speed, but this reflects an obvious trend. The ignition delay of the fuels decreases with increasing load, but ethanol extends this duration. The variation of combustion duration is opposite that of ignition delay, and ethanol slightly shortens the combustion duration. For instance, the combustion of pure biodiesel at $30 \mathrm{Nm}$ lasts $20.95{ }^{\circ} \mathrm{CA}$, and $15 \%$ ethanol shortens this phase to $19.55^{\circ} \mathrm{CA}$. 


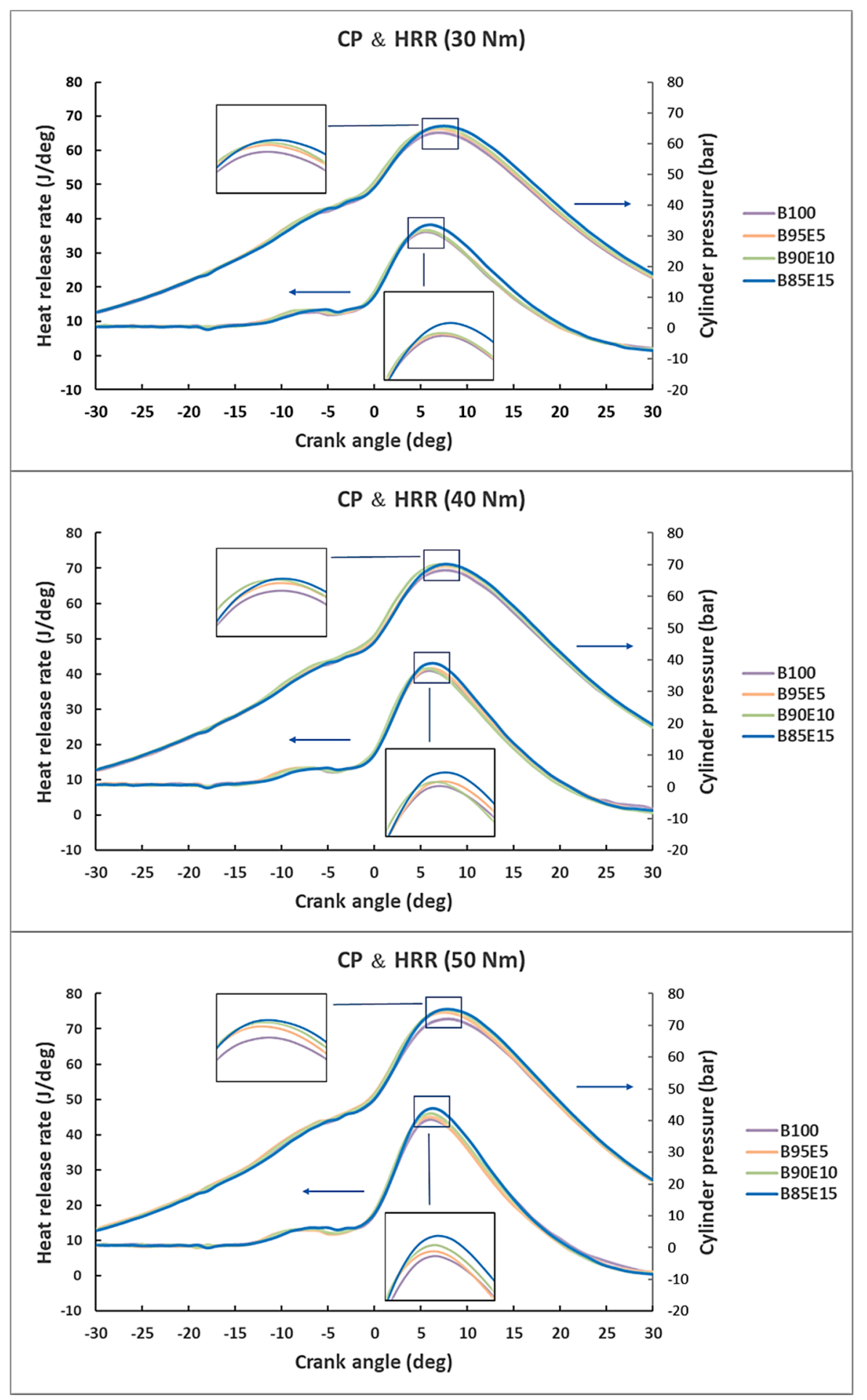

Figure 2. $\mathrm{CP}$ and HRR values of the blends. 
Table 4. CPmax, HRRmax, ignition delay, and combustion duration values of the blends.

\begin{tabular}{cccccc}
\hline Fuel & $\begin{array}{c}\text { Load } \\
(\mathbf{N m})\end{array}$ & $\begin{array}{c}\text { CPmax } \\
(\mathbf{b a r})\end{array}$ & $\begin{array}{c}\text { HRRmax } \\
(\mathbf{J} / \mathbf{d e g})\end{array}$ & $\begin{array}{c}\text { Ignition } \\
\text { Delay }\left({ }^{\circ} \mathbf{C A}\right)\end{array}$ & $\begin{array}{c}\text { Combustion } \\
\text { Duration }\left({ }^{\circ} \mathbf{C A}\right)\end{array}$ \\
\hline \multirow{3}{*}{ B100 } & 30 & 65.2 & 31.27 & 5.45 & 20.95 \\
& 40 & 69.3 & 36.69 & 5.4 & 21.35 \\
& 50 & 72.9 & 39.23 & 5.3 & 22 \\
\hline \multirow{3}{*}{ B95E5 } & 30 & 66.4 & 31.57 & 5.65 & 20.4 \\
& 40 & 70.5 & 37.07 & 5.55 & 21.35 \\
B90E10 & 50 & 74.6 & 41.13 & 5.43 & 21.17 \\
& 30 & 66.8 & 31.77 & 6.15 & 20 \\
\hline \multirow{3}{*}{ B85E15 } & 40 & 71 & 37.15 & 6 & 20.4 \\
& 50 & 75.3 & 42.31 & 5.8 & 19.55 \\
\hline
\end{tabular}

Adding ethanol, with a lower cetane number than biodiesel, reduces the cetane number of blended fuels. When ethanol evaporates, it absorbs heat in the cylinder, reduces the temperature in the cylinder, and extends the ignition delay of the blended fuel $[17,26,27]$. Therefore, the fuel with the highest ethanol content has the longest ignition delay under various conditions, which is consistent with previous findings [17,27]. A long ignition delay provides a longer fuel-air mixing period, which promotes higher CPmax and HRRmax. The oxygen content of the ethanol used in the test was as high as $34.7 \%$, which increases the oxygen concentration in the fuel and is conducive to improved premixed combustion [26]. The viscosity and density of the blended fuels are better than those of pure biodiesel, and fuel injection atomization has a positive effect. Ethanol can shorten the fuel breakup length, increase the spray angle, refine the sprayed droplets, and help improve the degree of mixing [28], which helps to optimize combustion quality. The higher oxygen content in the ethanol-biodiesel blends spray reduces pyrolysis, increases oxidation, and improves diffusion combustion, shortening the combustion duration [17]. A longer ignition delay can cause greater fuel consumption in the premixing period and lesser consumption during diffusion combustion, resulting in a shorter combustion duration as ethanol content increases [29].

\subsection{Engine Performance}

The variation in braking-specific fuel consumption (BSFC) with ethanol volume and load is depicted in Figure 3. The difference in fuel calorific value shown in Figure 3 is the key to this trend. The calorific value of the blended fuel decreases with the increasing amount of ethanol. Therefore, under the same load, a fuel with a high ethanol concentration often must be injected at a larger volume to compensate for the effects of calorific value [26]. 


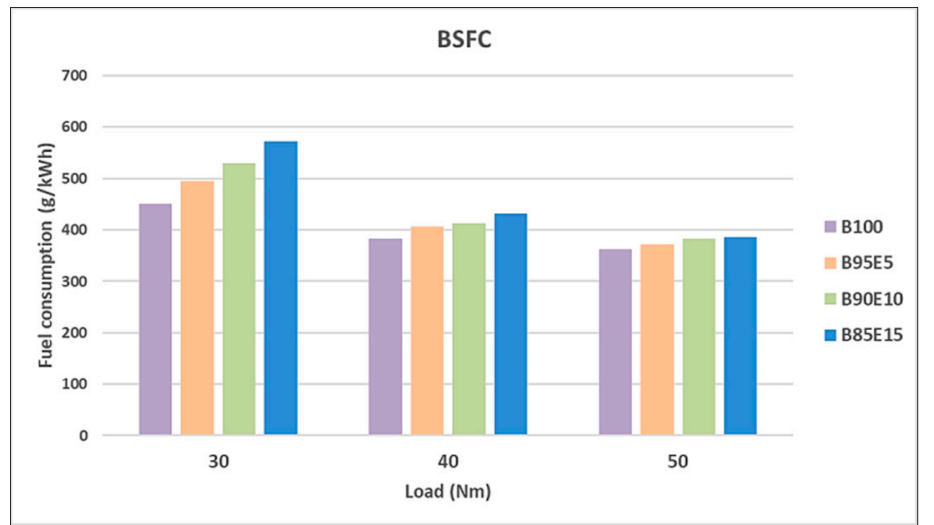

Figure 3. Braking-specific fuel consumption (BSFC) of blended fuels under loads of 30, 40, and $50 \mathrm{Nm}$.

As illustrated in Figure 4, the ethanol in fuel reduces the braking thermal efficiency (BTE) proportional to the volume of ethanol contained. The calorific value of ethanol and the larger latent heat of vaporization result in a lower temperature in the cylinder, which is not conducive for thorough combustion [30]. This negative effect is slightly weakened by a load increase. Compared with pure biodiesel, the BTE values of 5, 10, and 15\% ethanol at a load of $30 \mathrm{Nm}$ were reduced by $8.9,14.9$, and $21.2 \%$, respectively, but the decreases were reduced to $2.3,5.3$, and $5.9 \%$ at a load of $50 \mathrm{Nm}$.

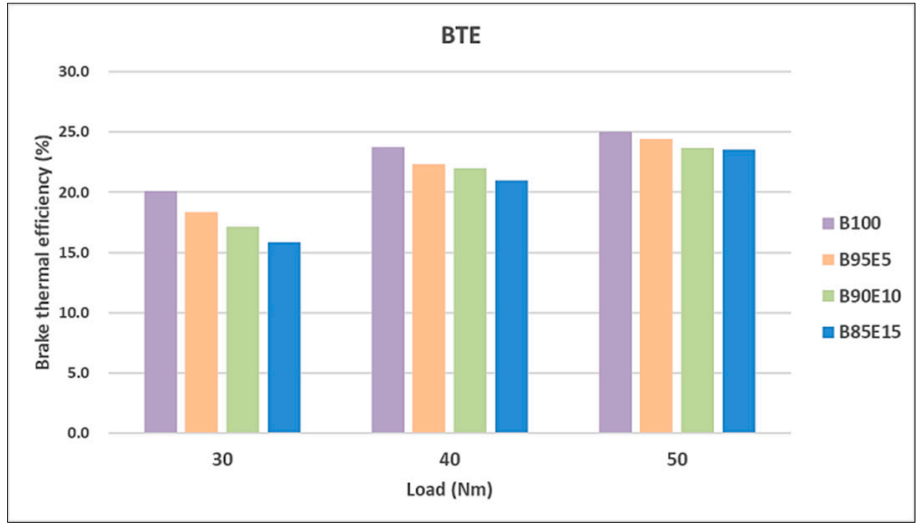

Figure 4. Braking thermal efficiency (BTE) of blended fuels under loads of 30, 40, and $50 \mathrm{Nm}$.

The coefficient of variation of indicated mean effective pressure (COVimep) reflects the cyclic variation of engine combustion, and a variation coefficient less than $10 \%$ is acceptable because a low coefficient of variation indicates stable combustion quality. The coefficient of variation of each fuel for 200 cycles is shown in Figure 5. The maximum COVimep of B100 can reach 2.3\%, but the COVimep of the blended fuels after adding ethanol is lower than $1.67 \%$. Some studies $[31,32]$ have pointed out that the increase in ethanol content increases the COVimep of the fuel, but the performance observed under this test condition is different. The effect of ethanol on combustion improvement under idling conditions is obvious, similar to previous experimental results [27]. Fuel with a higher concentration of ethanol tends to be more stable, especially at $50 \mathrm{Nm}$, where the COVimep values of the four fuels are more similar to each other, which means that the advantages of the ethanol-biodiesel blends are diminished. 


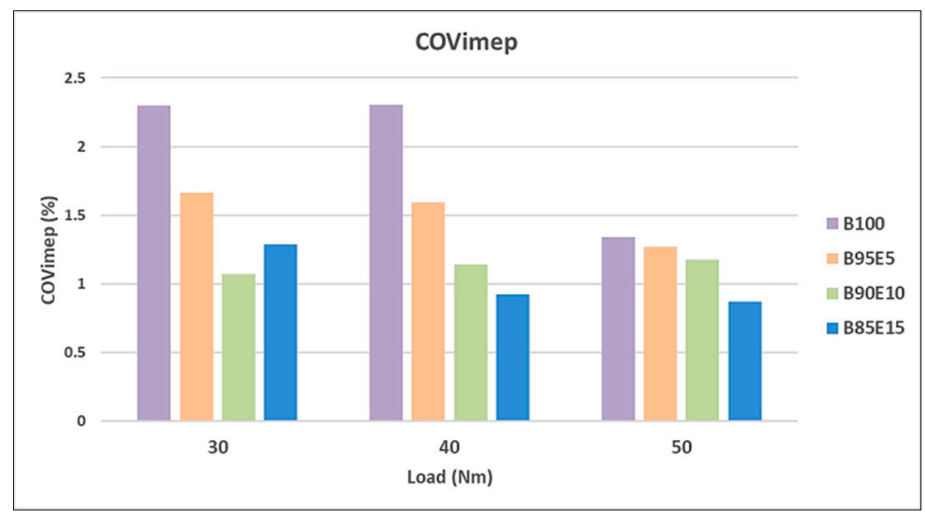

Figure 5. COVimep of blended fuels under loads of 30, 40, and $50 \mathrm{Nm}$.

The exhaust gas temperature (EGT) shown in Figure 6 provides information about the combustion process. At $30 \mathrm{Nm}$, the exhaust temperatures of B100, B95E5, B90E10, and B85E15 were 194, 193, 193, and $194^{\circ} \mathrm{C}$, respectively. After the load increased to $50 \mathrm{Nm}$, the exhaust temperatures of these four fuels increased to $244,246,245$, and $242{ }^{\circ} \mathrm{C}$, respectively. The exhaust temperature increases with increasing load, but the effect on exhaust temperature caused by ethanol is minimal, which is consistent with a previous finding [4].

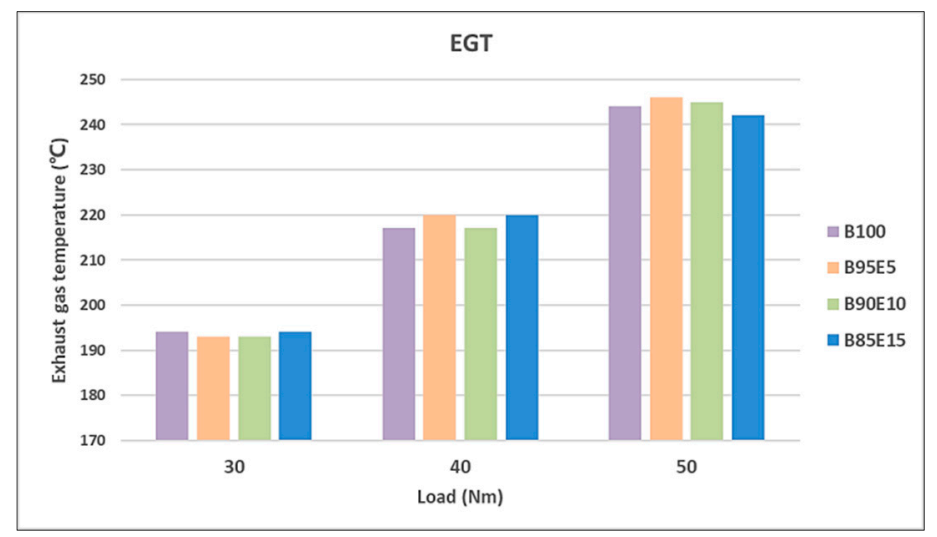

Figure 6. Exhaust gas temperature (EGT) of blended fuels under loads of 30, 40, and $50 \mathrm{Nm}$.

\subsection{Emissions Characteristics}

The $\mathrm{CO}$ emissions from the engine are shown in Figure 7. Obviously, the CO emissions of all fuels decrease as load increases. This might be because the pressure in the cylinder increases with load, and a larger pressure in the cylinder is conducive to more complete fuel combustion, which is consistent with the variation in cylinder pressure peak reported previously [3]. Under all tested loads, all ethanol-containing fuels showed good CO emission reduction effects. However, under loads of 30 and $40 \mathrm{Nm}$, CO emissions slightly increased with increasing ethanol concentration. This is because the ethanol in the blended fuel contains a large amount of hydroxyl groups, and the release of hydroxyl groups in the cylinder is beneficial to the oxidation of $\mathrm{CO}$ to $\mathrm{CO}_{2}$, thereby reducing the presence of $\mathrm{CO}$ [3]. However, the higher latent heat of vaporization of ethanol reduces the gas temperature in the cylinder [26,33] and complete oxidation of CO cannot be achieved [33]; fuels with higher concentrations of ethanol at low loads produce higher $\mathrm{CO}$ emissions. 


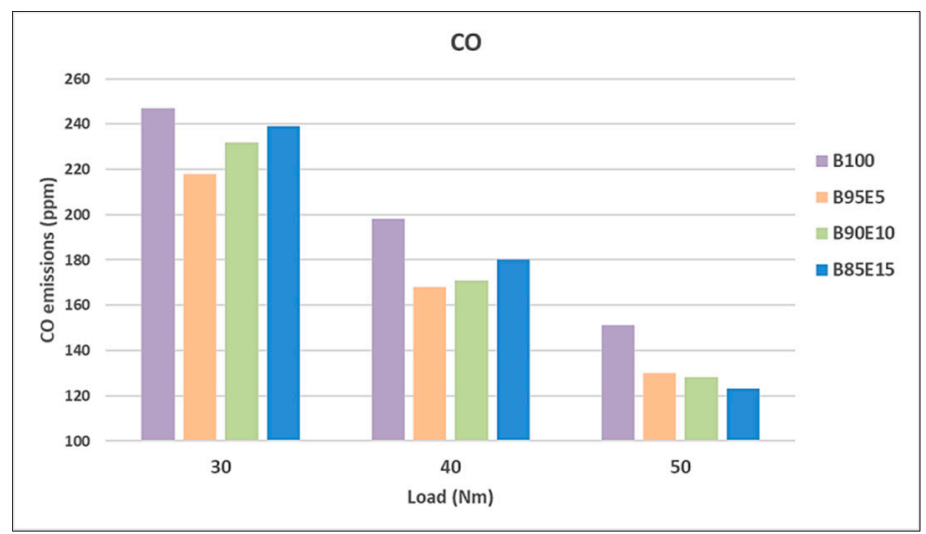

Figure 7. CO emissions of blended fuels under loads of 30, 40, and $50 \mathrm{Nm}$.

Figure 8 illustrates the $\mathrm{HC}$ emission characteristic of the fuels. The $\mathrm{HC}$ emissions of the four fuels increased as load increased from 30 to $50 \mathrm{Nm}$. The low-load ignition delay is longer, allowing better entrance of the oil and gas mixture into the cylinder gap, which intensifies the narrow gap effect. The increasing fuel injection quantity with increasing load and the narrow gap effect promote the formation of greater HC emissions [34]. Furthermore, the addition of ethanol encourages the generation of $\mathrm{HC}$, and $\mathrm{HC}$ displacement is positively correlated with ethanol volume concentration. Yilmaz et al. explored the effect of ethanol concentration on HC produced by blended fuels and observed a similar trend. They explained that the cooling effect of ethanol at a high concentration is dominant under a low load, and only at a low concentration can it exert the advantage of its high oxygen content [35].

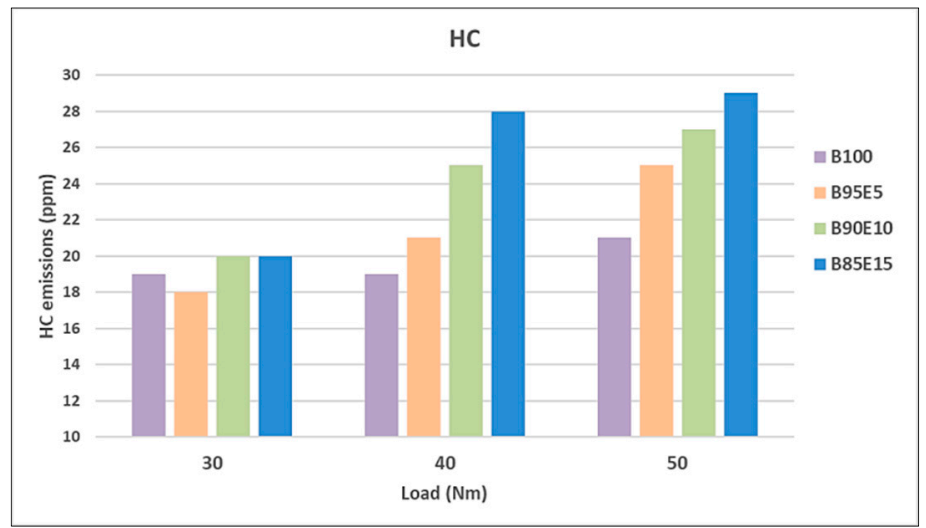

Figure 8. HC emissions of blended fuels under loads of 30, 40, and $50 \mathrm{Nm}$.

Figure 9 shows the NOx emission characteristic of the fuels. The addition of ethanol to biodiesel promotes the formation of NOx, and the amount of NOx emissions is positively correlated with the concentration of ethanol. The lower cetane number of ethanol extends the ignition time. As the ethanol concentration in the fuel increases, the cetane number of the blended fuel also increases, and the ignition delay becomes longer. It is beneficial to the air-fuel mixture to release heat faster, leading to an increase in temperature and enhanced NOx emissions [36]. Meanwhile, ethanol increases the oxygen content of the blended fuel, which also helps to increase the combustion temperature [37]. The NOx emission characteristics had similar results under loads of 30, 40, and $50 \mathrm{Nm}$. Among them, the promotion effect of ethanol on NOx was most obvious at $40 \mathrm{Nm}$. Concentrations of 5 , 10 , and $15 \%$ ethanol increased the NOx emissions by $15.9,19.7$, and $22.1 \%$, respectively, as shown in Figure 9. 


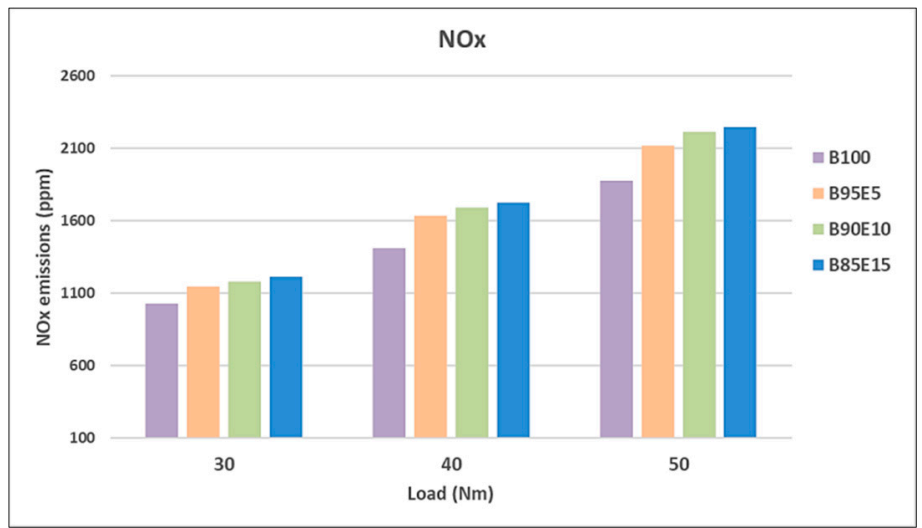

Figure 9. NOx emissions of blended fuels under loads of 30, 40, and $50 \mathrm{Nm}$.

The contribution of ethanol to smoke reduction is significant, as shown in Figure 10. As load increases, more fuel is injected into the cylinder, resulting in a greater equivalence ratio and greater fuel-rich area [38]. Therefore, a higher load promotes the formation of smoke from pure biodiesel. After adding ethanol, the smoke emissions of blended fuels are distinctly reduced, and as ethanol content increases, the reduction in emissions is greater. Ethanol increases the oxygen concentration in blended fuel and improves the combustion quality. Its lower carbon/hydrogen ratio inhibits the formation of particles and facilitates the oxidation of particles [26]. The greater latent heat of vaporization of ethanol reduces the temperature in the cylinder, and the longer ignition delay of the blended fuel is conducive to better mixing of oil and gas [26]. The smoke emissions of the ethanol-biodiesel blends did not increase with increasing load like they did in pure biodiesel. Ethanol had the greatest emission reduction effect under a load of $50 \mathrm{Nm}$, where $15 \%$ ethanol contributed a maximum reduction of $71 \%$.

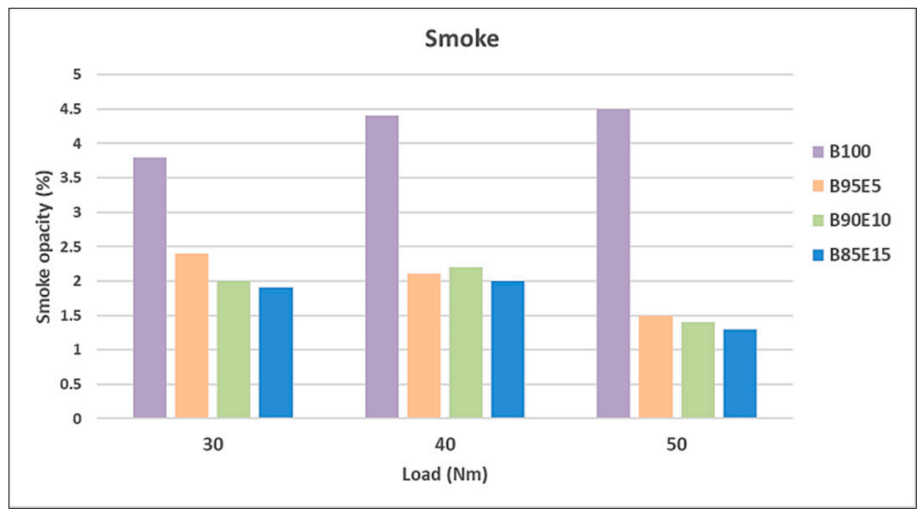

Figure 10. Smoke opacity values of blended fuels under loads of 30, 40, and $50 \mathrm{Nm}$.

\section{Conclusions}

In order to study the engine performance and combustion and emission characteristics of diesel engines at idle speed (750 rpm) with various low engine loads (30, 40, and $50 \mathrm{Nm}$ ), a series of experiments were carried out on a CRDI diesel engine fueled with ethanolbiodiesel blends containing $0,5,10$, and $15 \mathrm{vol} \%$ ethanol additives. The main findings are summarized as follows:

As the load increases at idling speed, the peaks of CP and HRR increase; additional ethanol also helps increase the peaks. The results showed that the maximum increase in CPmax for adding 5, 10, and $15 \mathrm{vol} \%$ ethanol is $2.33 \%, 3.29 \%$, and $3.7 \%$, respectively, and the heat release rate is $4.83 \%, 7.82 \%$, and $11.64 \%$.

- Although the addition of ethanol significantly enhances the BSFC, increasing the load can reduce it. The trend of BTE is opposite that of the BSFC as it decreases with increas- 
ing load and with increasing ethanol concentration. Increasing the ethanol content and load reduces the COVimep. EGT also increases significantly with increasing load, but the effect of ethanol is not obvious.

- Ethanol additives have an attenuation effect on $\mathrm{CO}$ and especially smoke. The maximum smoke reduction of the blends fuel with $15 \mathrm{vol} \%$ ethanol additive reached $71 \%$. The greater the load of ethanol, the more obvious the effect on smoke reduction. On the contrary, increases in load and ethanol content promote the generation of $\mathrm{HC}$ and NOx emissions.

Author Contributions: Methodology, G.W. and J.C.G.; investigation, G.W., J.C.G. and N.J.C.; data curation, G.W.; writing—original draft preparation, G.W.; writing-review and editing, J.C.G. and N.J.C.; funding acquisition, J.C.G. and N.J.C. All authors have read and agreed to the published version of the manuscript.

Funding: This research was funded by the Basic Science Research Program through the National Research Foundation of Korea (NRF) funded by the Ministry of Education, grant number 2019R1I1A1 A01057727, and the Korean government (MSIT), grant number 2019R1F1A1063154.

Data Availability Statement: The data presented in this study are available on request from the corresponding author.

Conflicts of Interest: The authors declare no conflict of interest.

\section{References}

1. Uyumaz, A. Combustion, performance and emission characteristics of a DI diesel engine fueled with mustard oil biodiesel fuel blends at different engine loads. Fuel 2018, 212, 256-267. [CrossRef]

2. Lapuerta, M.; Hernández, J.J.; Fernández-Rodríguez, D.; Cova-Bonillo, A. Autoignition of blends of $\mathrm{n}$-butanol and ethanol with diesel or biodiesel fuels in a constant-volume combustion chamber. Energy 2017, 118, 613-621. [CrossRef]

3. Paul, A.; Panua, R.; Debroy, D. An experimental study of combustion, performance, exergy and emission characteristics of a CI engine fueled by Diesel-ethanol-biodiesel blends. Energy 2017, 141, 839-852. [CrossRef]

4. Datta, A.; Mandal, B.K. Engine performance, combustion and emission characteristics of a compression ignition engine operating on different biodiesel-alcohol blends. Energy 2017, 125, 470-483. [CrossRef]

5. Ge, J.C.; Kim, H.Y.; Yoon, S.K.; Choi, N.J. Reducing volatile organic compound emissions from diesel engines using canola oil biodiesel fuel and blends. Fuel 2018, 218, 266-274. [CrossRef]

6. Mayo, M.P.; Boehman, A.L. Ignition behavior of biodiesel and diesel under reduced oxygen atmospheres. Energy Fuels 2015, 29, 6793-6803. [CrossRef]

7. Pullen, J.; Saeed, K. An overview of biodiesel oxidation stability. Renew. Sustain. Energy Rev. 2012, 16, 5924-5950. [CrossRef]

8. Fazal, M.A.; Haseeb, A.S.M.A.; Masjuki, H.H. Biodiesel feasibility study: An evaluation of material compatibility per-formance; emission and engine durability. Renew. Sustain. Energy Rev. 2011, 15, 1314-1324. [CrossRef]

9. Hosseinzadeh-Bandbafha, H.; Tabatabaei, M.; Aghbashlo, M.; Khanali, M.; Demirbas, A. A comprehensive review on the environmental impacts of diesel/biodiesel additives. Energy Convers. Manag. 2018, 174, 579-614. [CrossRef]

10. Kannan, G.; Karvembu, R.; Anand, R. Effect of metal based additive on performance emission and combustion charac-teristics of diesel engine fuelled with biodiesel. Appl. Energy 2011, 88, 3694-3703. [CrossRef]

11. Kumar, S.; Dinesha, P.; Rosen, M.A. Effect of injection pressure on the combustion, performance and emission character-istics of a biodiesel engine with cerium oxide nanoparticle additive. Energy 2019, 185, 1163-1173. [CrossRef]

12. Dagle, R.A.; Winkelman, A.D.; Ramasamy, K.K.; Dagle, V.L.; Weber, R.S. Ethanol as a renewable building block for fuels and chemicals. Ind. Eng. Chem. Res. 2020, 59, 4843-4853. [CrossRef]

13. Holladay, J.E.; Male, J.L.; Rousseau, R.; Weber, R.S. Synthesizing clean transportation fuels from $\mathrm{CO}_{2}$ will at least quintuple the demand for non-carbogenic electricity in the United States. Energy Fuels 2020, 34, 15433-15442. [CrossRef]

14. Xu, C.; Paone, E.; Rodríguez-Padrón, D.; Luque, R.; Mauriello, F. Reductive catalytic routes towards sustainable production of hydrogen, fuels and chemicals from biomass derived polyols. Renew. Sustain. Energy Rev. 2020, 127, 109852. [CrossRef]

15. Alptekin, E. Emission, injection and combustion characteristics of biodiesel and oxygenated fuel blends in a common rail diesel engine. Energy 2017, 119, 44-52. [CrossRef]

16. Zhan, C.; Feng, Z.; Ma, W.; Zhang, M.; Tang, C.; Huang, Z. Experimental investigation on effect of ethanol and di-ethyl ether addition on the spray characteristics of diesel/biodiesel blends under high injection pressure. Fuel 2018, 218, 1-11. [CrossRef]

17. Zhu, L.; Cheung, C.; Zhang, W.; Huang, Z. Combustion, performance and emission characteristics of a DI diesel engine fueled with ethanol-biodiesel blends. Fuel 2011, 90, 1743-1750. [CrossRef]

18. Pradelle, F.; Braga, S.L.; Martins, A.R.F.D.A.; Turkovics, F.; Pradelle, R.N.C. Experimental assessment of some key physicochemical properties of diesel-biodiesel-ethanol (DBE) blends for use in compression ignition engines. Fuel 2019, 248, 241-253. [CrossRef] 
19. Madiwale, S.; Karthikeyan, A.; Bhojwani, V. Properties investigation and performance analysis of a diesel engine fuelled with jatropha, soybean, palm and cottonseed biodiesel using ethanol as an additive. Mater. Today Proc. 2018, 5, 657-664. [CrossRef]

20. Rahman, S.A.; Masjuki, H.; Kalam, M.; Abedin, M.; Sanjid, A.; Sajjad, H. Production of palm and Calophyllum inophyllum based biodiesel and investigation of blend performance and exhaust emission in an unmodified diesel engine at high idling conditions. Energy Convers. Manag. 2013, 76, 362-367. [CrossRef]

21. Rahman, S.A.; Masjuki, H.; Kalam, M.; Abedin, M.; Sanjid, A.; Rahman, M. Assessing idling effects on a compression ignition engine fueled with Jatropha and Palm biodiesel blends. Renew. Energy 2014, 68, 644-650. [CrossRef]

22. Yasin, M.H.M.; Mamat, R.; Najafi, G.; Ali, O.M.; Yusop, A.F.; Ali, M.H. Potentials of palm oil as new feedstock oil for a global alternative fuel: A review. Renew. Sustain. Energy Rev. 2017, 79, 1034-1049. [CrossRef]

23. Mekhilef, S.; Siga, S.; Saidur, R. A review on palm oil biodiesel as a source of renewable fuel. Renew. Sustain. Energy Rev. 2011, 15, 1937-1949. [CrossRef]

24. Ong, H.; Mahlia, T.; Masjuki, H.; Norhasyima, R. Comparison of palm oil, Jatropha curcas and Calophyllum inophyllum for biodiesel: A review. Renew. Sustain. Energy Rev. 2011, 15, 3501-3515. [CrossRef]

25. Dey, S.; Reang, N.; Das, P.; Deb, M. A comprehensive study on prospects of economy, environment, and efficiency of palm oil biodiesel as a renewable fuel. J. Clean. Prod. 2021, 286, 124981. [CrossRef]

26. Wei, L.; Cheung, C.; Ning, Z. Effects of biodiesel-ethanol and biodiesel-butanol blends on the combustion, performance and emissions of a diesel engine. Energy 2018, 155, 957-970. [CrossRef]

27. Kim, H.Y.; Ge, J.C.; Choi, N.J. Effects of ethanol-diesel on the combustion and emissions from a diesel engine at a low idle speed. Appl. Sci. 2020, 10, 4153. [CrossRef]

28. Jiang, Z.; Gan, Y.; Ju, Y.; Liang, J.; Zhou, Y. Experimental study on the electrospray and combustion characteristics of biodieselethanol blends in a meso-scale combustor. Energy 2019, 179, 843-849. [CrossRef]

29. Tse, H.; Leung, C.W.; Cheung, C.S. Investigation on the combustion characteristics and particulate emissions from a diesel engine fueled with diesel-biodiesel-ethanol blends. Energy 2015, 83, 343-350. [CrossRef]

30. Khoobbakht, G.; Karimi, M.; Kheiralipour, K. Effects of biodiesel-ethanol-diesel blends on the performance indicators of a diesel engine: A study by response surface modeling. Appl. Eng. 2019, 148, 1385-1394. [CrossRef]

31. Tutak, W.; Jamrozik, A.; Pyrc, M.; Sobiepański, M. A comparative study of co-combustion process of diesel-ethanol and biodiesel-ethanol blends in the direct injection diesel engine. Appl. Therm. Eng. 2017, 117, 155-163. [CrossRef]

32. Padala, S.; Woo, C.; Kook, S.; Hawkes, E.R. Ethanol utilisation in a diesel engine using dual-fuelling technology. Fuel 2013, 109, 597-607. [CrossRef]

33. Shamun, S.; Belgiorno, G.; Di Blasio, G.; Beatrice, C.; Tunér, M.; Tunestål, P. Performance and emissions of die-sel-biodiesel-ethanol blends in a light duty compression ignition engine. Appl. Therm. Eng. 2018, 145, 444-452. [CrossRef]

34. Xiao, H.; Guo, F.; Wang, R.; Yang, X.; Li, S.; Ruan, J. Combustion performance and emission characteristics of diesel engine fueled with iso-butanol/biodiesel blends. Fuel 2020, 268, 117387. [CrossRef]

35. Yilmaz, N. Comparative analysis of biodiesel-ethanol-diesel and biodiesel-methanol-diesel blends in a diesel engine. Energy 2012, 40, 210-213. [CrossRef]

36. Kandasamy, S.K.; Selvaraj, A.S.; Rajagopal, T.K.R. Experimental investigations of ethanol blended biodiesel fuel on au-tomotive diesel engine performance, emission and durability characteristics. Renew. Energy 2019, 141, 411-419. [CrossRef]

37. Barabás, I.; Todorut, A.; Băldean, D. Performance and emission characteristics of an CI engine fueled with diesel-biodieselbioethanol blends. Fuel 2010, 89, 3827-3832. [CrossRef]

38. Zheng, Z.; Xia, M.; Liu, H.; Wang, X.; Yao, M. Experimental study on combustion and emissions of dual fuel RCCI mode fueled with biodiesel/n-butanol, biodiesel/2,5-dimethylfuran and biodiesel/ethanol. Energy 2018, 148, 824-838. [CrossRef] 